Case Report

\title{
Complex and Multifaceted Therapy-Related Myeloid Neoplasm Following Laryngeal Cancer Treated with Cisplatin and Radiotherapy
}

Pasquale Niscola ${ }^{1}$, Gianfranco Catalano ${ }^{1}$, Andrea Tendas ${ }^{1}$, Marco Giovannini ${ }^{1}$, Laura Scaramucci ${ }^{1}$, Benedetta Neri $^{1}$, Luciana Morino ${ }^{1}$, Daniela Piccioni ${ }^{1}$, Stefano Fratoni ${ }^{2}$, Alessio Perrotti ${ }^{1}$ and Paolo de Fabritiis ${ }^{1}$.

${ }^{1}$ Hematology Unit, S. Eugenio Hospital, Rome, Italy.

${ }^{2}$ Pathology Department, S. Eugenio Hospital, Rome, Italy.

Correspondence to: Pasquale Niscola M. D., Division of Hematology, Tor Vergata University, Sant'Eugenio Hospital, Rome (Italy). Tel +390651003241, Fax +390651002390. E-mail address: pniscola@ gmail.com

Competing interests: The authors have declared that no competing interests exist.

Published: April 15, 2013

Received: December 13, 2012

Accepted: March 29, 2013

Citation: Mediterr J Hematol Infect Dis 2013, 5(1): e2013030, DOI: 10.4084/MJHID.2013.030

This article is available from: http://www.mjhid.org/article/view/11314

This is an Open Access article distributed under the terms of the Creative Commons Attribution License (http://creativecommons.org/licenses/by/2.0), which permits unrestricted use, distribution, and reproduction in any medium, provided the original work is properly cited.

Introduction. Therapy-related myeloid neoplasm, usually in the forms of myelodysplastic syndromes/acute myeloid leukemias (t-MDS/AML), are well-known secondary malignancies occurring in cancer patients who received chemo-radiotherapy regimens, especially those including alkylating agents and topoisomerase II inhibitors. ${ }^{1}$ The leukemogenic potential of other compounds, such as platinum drugs, is less clearly established, ${ }^{2}$ although a slightly increased risk of secondary AML has been reported after therapy for ovarian ${ }^{3}$ and testicular ${ }^{4}$ cancers. We describe the quite rare occurrence of a myelodysplastic/ myeloproliferative neoplasm (MDS/MPN) with multiple accumulating genetic anomalies not usually found together as JAK2 V617F, IDH2 R172K and 7qdeletion, after exposure to radiotherapy and platinum based chemotherapeutic agents in a patient treated for laryngeal cancer.

Case presentation. A 60 years old man came to our attention on May 2011 because of isolated thrombocytopenia. He had been submitted to total laryngectomy for a laryngeal cancer, (May 2010) followed by local radiation (total dose: $6420 \mathrm{cGy}$ ) and chemotherapy. Cisplatin was given as a single agent with an adapted schedule (cumulative dose: $428 \mathrm{mg}$ ), due to a prolonged pancytopenia following administration of the first dose and an overall poor hematological tolerance. One year after chemotherapy the patient was referred to our outpatient clinic, due to mild asymptomatic thrombocytopenia (platelet count: 97.000/uL). Palpable splenomegaly, estimated by ultrasonography as of $20 \mathrm{~cm}$ longitudinal diameter, was present. Peripheral blood (PB) smears showed a pronounced anisocytosis and poikilocytosis of red blood cells (RBC) and platelets (PLTS) and the absence of morphological evidence of circulating blasts. Trephine biopsy revealed a hypercellular bone marrow (BM) indicative of refractory cytopenia with multilineage dysplasia (RCMD, figure 1a-c), mild and multifocal reticulin fibrosis (grade 1 according to European Consensus System) $)^{5}$ and about $3 \%$ of immature-blastic cells. Standard cytogenetic and FISH analysis on $\mathrm{BM}$ and $\mathrm{PB}$ showed no abnormalities (normal karyotype). BCR/ABL p210 and p190 molecular transcripts were not detectable, whereas a mutation of JAK2 V617F was present at quantitative PCR analysis. The diagnosis was of myelodysplastic/ myeloproliferative neoplasm (MDS/MPN). Considering the temporal relation, we suspected a link 


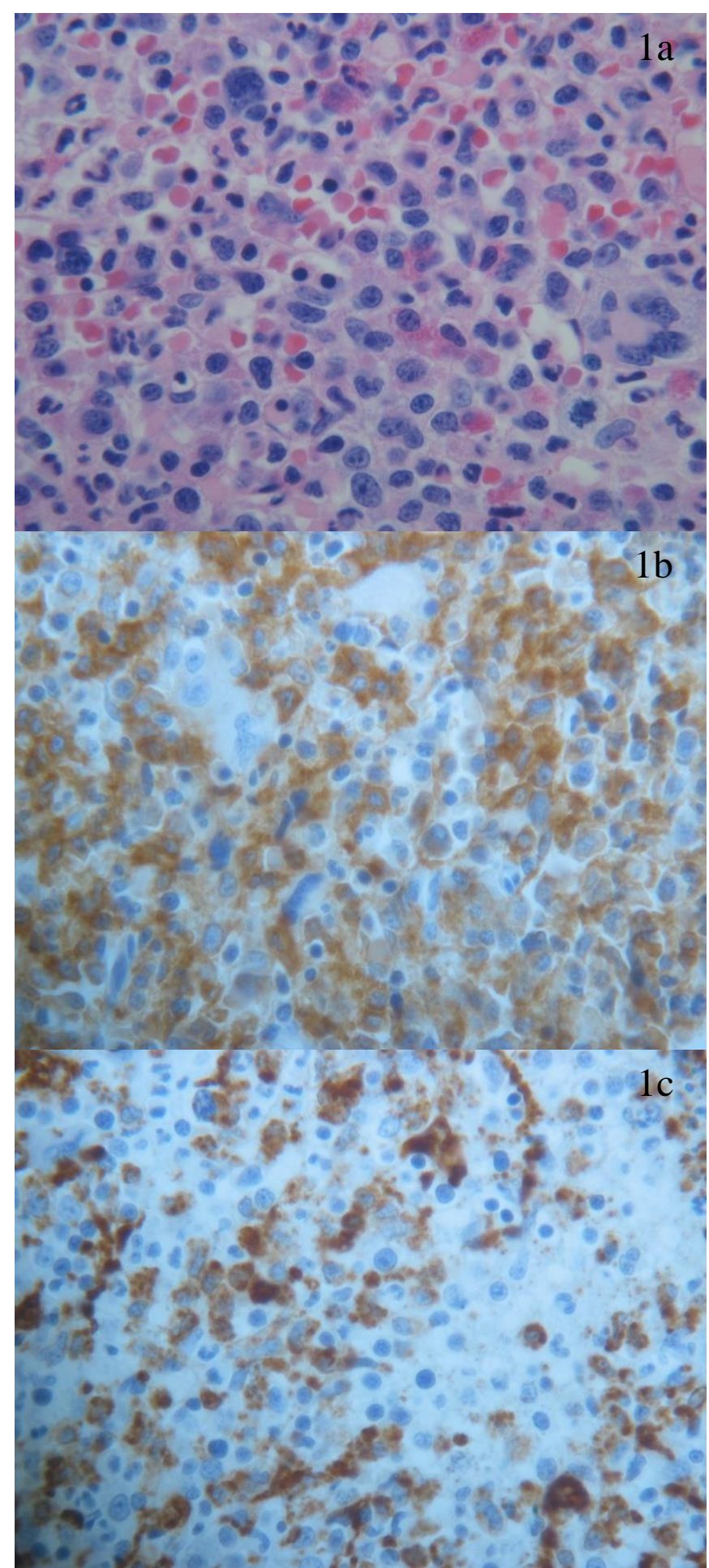

Figure 1. BM biopsy, high magnification (x 40) shows prominent myeloid proliferation (a); elements with myelomonocytic morphology expressing CD33 (b) and CD68RPGM1 (c) are prevalent. Dysplastic granulocytopoiesis and megakaryocytopoiesis are evident. Cells with undifferentiated immature morphology or blast equivalent as monoblast or promonocytes are very rare.

with the previous cytotoxic treatments for laryngeal cancer. Ten months after the initial diagnosis of MDS/MPN, the patient presented a rapidly progressive spleen enlargement leading within few weeks to massive and painful splenomegaly. $\mathrm{He}$ received hydroxycarbamide without benefit. While his blood

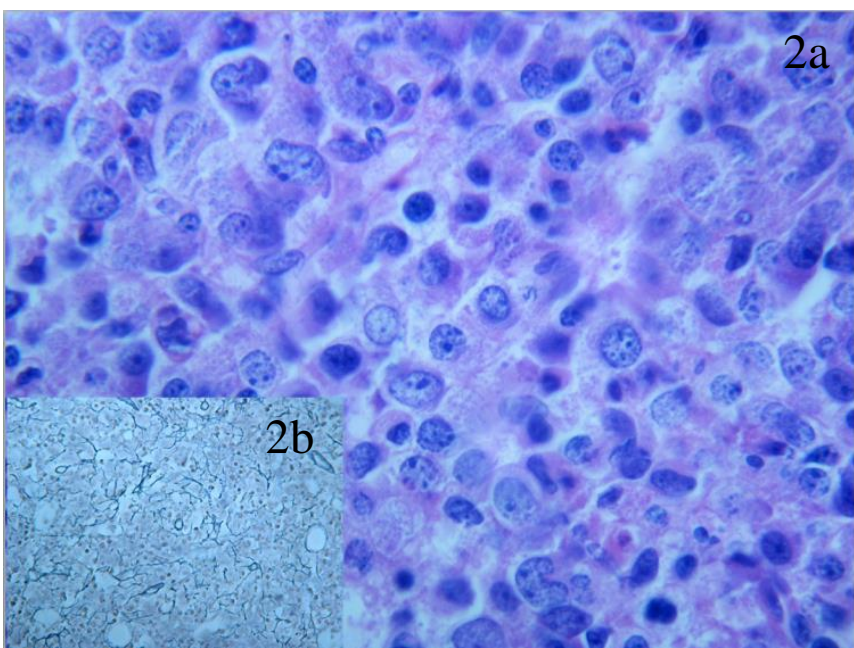

Figure 2. BM with large amount of monocytes and myeloid precursor such as promonocytes and cells with immature morphology featuring atypical nuclear anomalies, finely dispersed chromatin, small evident nucleoli and scant cytoplasm. Those cells are CD34 negative but express CD68KP1 and CD68RPGM1 (data not shown). The percentage of immature precursor through the entire BM biopsy has been estimated at about $15-20 \%$ of all hematopoietic cells. These findings were consistent with the diagnosis of chronic myelomonocytic leukemia- type 2 (a). Insert b is a Gomori stain which shows a delicate bone marrow fibrosis, grade- 1 .

counts did progressively deteriorate, an increasing monocytosis was recorded. A hematological diagnostic revision was performed with histopathological diagnosis of CMML with $15 \%$ of blasts in the BM (Figure 2a,b). MD Anderson Prognostic Scoring System (MDAPS) ${ }^{7}$ was 4 (high risk). The patient received palliative local radiotherapy with significant benefit, due to the extremely high symptoms burden of massive splenomegaly $(27 \times 20 \mathrm{~cm}$ on $\mathrm{CT}$ scan evaluation). Immediately after he was scheduled to receive six cycles of azacitidine $\left(75 \mathrm{mg} / \mathrm{m}^{2}\right.$, schedule $5+2$ days excluding weekends, each cycle every 4 weeks), in the light of favorable reported experiences ${ }^{8,9}$ and according to the approved indications. The patient was properly informed and gave his consent. After the fourth azacitidine course, PB counts significantly improved, and the monocytosis disappeared; BM trephine biopsy showed the near full disappearance of blast cells but progression of the fibrosis (Figure 3a,b). The spleen was once again massively enlarged; JAK2 V617F mutation was still present. The treatments were well tolerated and no major clinical complications were observed; in particular, only mild transfusion requirement was recorded. Meanwhile, a HLAidentical sibling donor was found in order to plan allogenic stem cells transplantation (HSCT). Unfortunately, soon after the completion of the sixth course of azacitidine, an overt evolution into AML (myelomonoblastic subtype) occurred. The patient presented marked leukocytosis $(\mathrm{WBC}=120.000 / \mathrm{ul}$; $70 \%$ myelomonoblastic cells positive for HLA- 


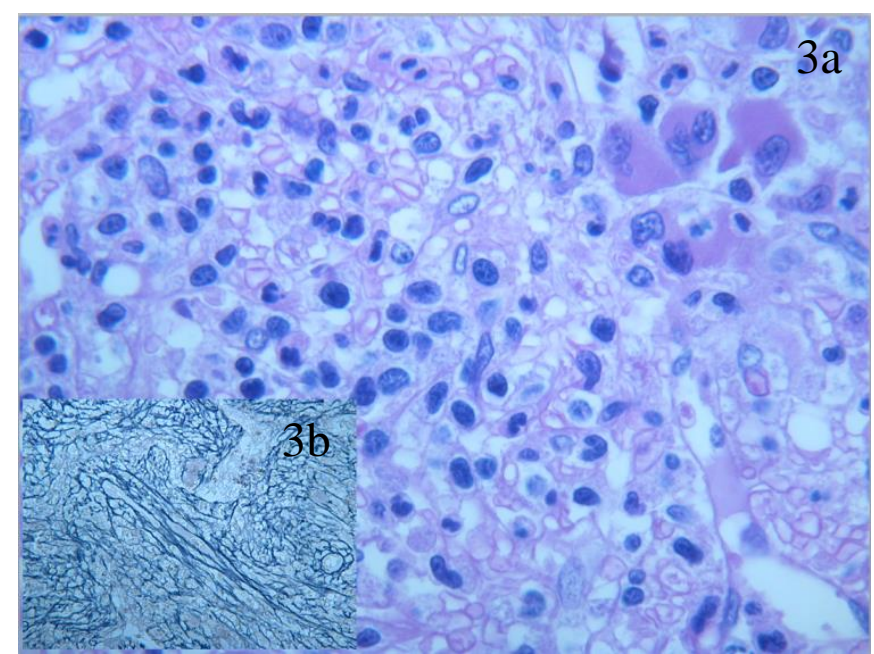

Figure 3. BM after azacitidine therapy reveals myelodysplastic features: dismegakariocytopoiesis and disgranulocytopoiesis are evident; rare erytroid islands with dyserythropoietic morphology are also detected (a). Cells with immature-blastic morphology are rare (less than 5\%). Insert b: Gomori stain shows a diffuse and strong (grade-2) BM fibrosis.

DR, CD4, CD13, CD15, CD33, CD64, CD45, CD34, CD56 and CD117). The kariotype by standard cytogenetic was: 46, XY, del (7)(q31)[7]/46,XY[13]; FISH analysis confirmed the deletion of the long arm of chromosome 7 in $80 \%$ of blastic cells. Molecular studies for the most frequent AML-related alterations (CBFb/MYH11, DEK/CAN, NPM1, FLT3, RUNX1/ETO) showed no abnormalities. Apart from the persistence of JAK2 V617F mutation, the analysis of most common alterations found in t-MDS/AML showed only an IDH2 R172K mutation. ${ }^{10}$ After the fourth azacitidine course, PB counts significantly improved, and the monocytosis disappeared; BM trephine biopsy showed the near full disappearance of blast cells but progression of the fibrosis (Figure 3a,b). The spleen was once again massively enlarged; JAK2 V617F mutation was still present. The treatments were well tolerated, and no major clinical complications were observed; in particular, only mild transfusion requirement was recorded. Meanwhile, a HLAidentical sibling donor was found in order to plan allogenic stem cells transplantation (HSCT). Unfortunately, soon after the completion of the sixth course of azacitidine, an overt evolution into AML (myelomonoblastic subtype) occurred. The patient presented marked leukocytosis $(\mathrm{WBC}=120.000 / \mathrm{ul}$; 70\% myelomonoblastic cells positive for HLADR,CD4,CD13,CD15,CD33,CD64, CD45,CD34,CD56 and CD117). The kariotype by standard cytogenetic was: 46, XY, del (7)(q31)[7]/46,XY[13]; FISH analysis confirmed the deletion of the long arm of chromosome 7 in $80 \%$ of blastic cells. Molecular studies for the most frequent AML-related alterations (CBFb/MYH11, DEK/CAN, NPM1, FLT3, RUNX1/ETO) showed no abnormalities. Apart from the persistence of JAK2
V617F mutation, the analysis of most common alterations found in t-MDS/AML showed only an IDH2 R172K mutation. The patient subsequently underwent to a chemotherapeutic treatment AML-like (FLA regimen) in order to submit him to a subsequent allogeneic bone marrow transplantation. However, the disease was resistant, and the patient died for pulmonary complications.

Conclusion. Cisplatin is a DNA-damaging drug, which exerts his cytotoxic properties by binding nuclear DNA, and then the most sensitive region of the genome such as telomeres interfering with normal transcription and replication mechanisms. ${ }^{11}$ DNA repair capacity, apart from being a major factor in conferring cisplatin resistance, may as well save partly damaged hemopoietic stem cells, giving rise to neoplastic clones. In addition, non-DNA targets, such as proteins, may contribute to cytotoxic effects induced by this agent. ${ }^{12}$ Although well described in the literature, therapy-related myeloid neoplasm after platinum-based chemotherapy and low dose local radiotherapy for solid tumors represents a rare occurrence. $^{2}$ Within one year after he received cisplatin, our patient was diagnosed with an unusual MDS/MPN disorder in prefibrotic phase, characterized by a hypercellular BM and minimal fibrosis; the hematological features of the disease in a short time changed in an accelerated and "subacute" fashion until full development of CMML. As secondary and therapy-related neoplasm, the latter has been only occasionally reported in the settings of solid tumors ${ }^{13,14}$ and hematological malignancies. ${ }^{15,16}$ A true link between the antineoplastic treatments for laryngeal cancer and the close onset of the atypical MDS/MPN disorder is difficult to assess; however, we consider this relationship at least conceivable due to the time course of events. The second course of radiotherapy on the spleen could have had a role in multiplying the damage initiated by cisplatin and the first course of radiotherapy. One can speculate that the second course of radiotherapy on the spleen stopped the repair of DNA sequence, easing the occurrence of the secondary leukemic event.

The sequence of events could be: Development of secondary JAK2 V617F myelomonocitic neoplasm, transformation in a more aggressive form as CMML and finally AML with IDH2 mutation and 7qdeletion.

Leukemic transformation of chronic MPNs is well known and relevant in the clinic, but very little is known about its molecular mechanisms of progression. We know that a substantial proportion of patients with JAK2V617F-mutant MPNs turns into a JAK2V617F-negative secondary AML (sAML). In our 
case the proliferative stimulus provided by JAK2 constitutively active kinase never defaulted, not even after hypomethylating therapy. Regarding IDH1/2 mutations, those are commonly identified in secondary gliomas that arise from a preceding lower-grade astrocytoma, suggesting a role in the progression to high-grade neoplasms. ${ }^{17} \mathrm{IDH} 2$ is the mitochondrial form of the three isocitrate dehydrogenase genes (IDH1-2-3). ${ }^{18-20}$ That anomaly gains to the enzyme the function of 2-hydoxiglutarate production with methabolic implications yet not well elucidated. It

\section{References:}

1. Leone G, Pagano L, Ben-Yehuda D, Voso MT. Therapy-related leukemia and myelodysplasia: susceptibility and incidence. Haematologica. 2007 Oct; 92(10):1389-98. http://dx.doi.org/10.3324/haematol.11034 PMid:17768113

2. Kim KB, Faderl S, Hwang CS, Khuri FR. Chronic myelomonocytic leukaemia after platinum-based therapy for non-small cell lung cancer: case report and review of the literature. J Clin Pharm Ther. 2006 Aug; 31(4):401-6. http://dx.doi.org/10.1111/j.1365-2710.2006.00748.x PMid:16882113

3. Travis LB, Holowaty EJ, Bergfeldt K, Lynch CF, Kohler BA, Wiklund T, Curtis RE, Hall P, Andersson M, Pukkala E, Sturgeon J, Stovall M. Risk of leukemia after platinum-based chemotherapy for ovarian cancer. N Engl J Med. 1999 Feb 4; 340(5):351-7.

http://dx.doi.org/10.1056/NEJM199902043400504

PMid:9929525

4. Travis LB, Andersson M, Gospodarowicz M, van Leeuwen FE, Bergfeldt K, Lynch CF, Curtis RE, Kohler BA, Wiklund T, Storm H, Holowaty E, Hall P, Pukkala E, Sleijfer DT, Clarke EA, Boice JD Jr, Stovall M, Gilbert E. Treatment-associated leukemia following testicular cancer. J Natl Cancer Inst. 2000 Jul 19; 92(14):1165-71 http://dx.doi.org/10.1093/inci/92.14.1165 PMid:10904090

5. Thiele J, Kvasnicka HM, Facchetti F, Franco V, van der Walt J, Orazi A. European consensus on grading bone marrow fibrosis and assessment of cellularity. Haematologica. 2005 Aug;90(8):1128-32. PMid:16079113

6. Bacher U, Schnittger S, Kern W, Weiss T, Haferlach T, Haferlach C. Distribution of cytogenetic abnormalities in myelodysplastic syndromes, Philadelphia negative myeloproliferative neoplasms, and the overlap MDS/MPN category. Ann Hematol. 2009 Dec;88(12):1207-13. http://dx.doi.org/10.1007/s00277-009-0745-3 PMid:19415278

7. Onida F, Kantarjian HM, Smith TL, Ball G, Keating MJ, Estey EH, Glassman AB, Albitar M, Kwari MI, Beran M. Prognostic factors and scoring systems in chronic myelomonocytic leukemia: a retrospective analysis of 213 patients. Blood. 2002 Feb 1;99 (3):840-9. http://dx.doi.org/10.1182/blood.V99.3.840 PMid:11806985

8. Fianchi L, Criscuolo M, Lunghi M, Gaidano G, Breccia M, Levis A, Finelli C, Santini V, Musto P, Oliva EN, Leoni P, Spiriti AA, D'Alò F, Hohaus S, Pagano L, Leone G, Voso MT. Outcome of therapy-related myeloid neoplasms treated with azacitidine. J Hematol Oncol. 2012 Aug 1;5:44.

http://dx.doi.org/10.1186/1756-8722-5-44 PMid:22853048 PMCid:3419605

9. Fianchi L, Criscuolo M, Breccia M, Maurillo L, Salvi F, Musto P, Mansueto G, Gaidano G, Finelli C, Aloe-Spiriti A, Santini V, Greco M, Hohaus S, Leone G, Voso MT. High rate of remissions in chronic myelomonocytic leukemia treated with 5-azacytidine: results of an Italian retrospective study. Leuk Lymphoma. 2012 Aug 30. [Epub ahead of print].

10. Jankowska AM, Makishima H, Tiu RV, Szpurka H, Huang Y, Traina F, Visconte V, Sugimoto Y, Prince C, O'Keefe C, Hsi ED, List A, Sekeres MA, Rao A, McDevitt MA, Maciejewski JP. Mutational spectrum analysis of chronic myelomonocytic seems to be relevant for cancer cell proliferation, may be through altering cellular respiration, and has been associated with unfavorable prognosis in $\mathrm{AML}^{21}$ In conclusion, we have reported on a patient with a likely therapy-related MDS/MPN, which initially appeared in the form of a prefibrotic atypical myeloid neoplasm with JAK2 V617F, rapidly transformed into a CMML and then in AML with multiple anomalies, all associated with an adverse prognosis, after a transient, brief response to epigenetic therapy.

leukemia includes genes associated with epigenetic regulation: UTX, EZH2, and DNMT3A. Blood. 2011 Oct 6;118(14):393241. $\quad$ http://dx.doi.org/10.1182/blood-2010-10-311019 PMid:21828135 PMCid:3193268

11. Sedletska Y, Giraud-Panis MJ, Malinge JM. Cisplatin is a DNAdamaging antitumour compound triggering multifactorial biochemical responses in cancer cells: importance of apoptotic pathways. Curr Med Chem Anticancer Agents. 2005 May;5(3):251-65. http://dx.doi.org/10.2174/1568011053765967 PMid:15992353

12. Cepeda V, Fuertes MA, Castilla J, Alonso C, Quevedo C, Pérez JM. Biochemical mechanisms of cisplatin cytotoxicity. Anticancer Agents Med Chem. 2007 Jan;7(1):3-18 http://dx.doi.org/10.2174/187152007779314044 PMid:17266502

13. Farhi DC, Odell CA, Shurin SB. Myelodysplastic syndrome and acute myeloid leukemia after treatment for solid tumors of childhood. Am J Clin Pathol. 1993 Sep; 100(3):270-5. PMid:8379535

14. Muroi K, Miyata T, Saito M, Hatake K, Amemiya Y, Miura Y. Therapy-related chronic myelomonocytic leukaemia with bone marrow eosinophilia associated with $\operatorname{der}(11) \mathrm{t}(1 ; 11)(\mathrm{q} 21 ; \mathrm{q} 14)$. Acta Haematol. 1996; 96(4):251-4 http://dx.doi.org/10.1159/000203795 PMid:8922495

15. Ueki K, Sato S, Tamura J, Sawamura M, Murakami H, Naruse $\mathrm{T}$, Tsuchiya J. Three cases of multiple myeloma developing into melphalan-related chronic myelomonocytic leukemia. J Med. 1991; 22(3):157-61. PMid:1770323

16. Natazuka T, Yamaguchi T, Murayama T, Fukase M, Matsui T, Isobe $\mathrm{T}$, Chihara K. Chronic myelomonocytic leukemia following prolonged alkylating agent therapy for multiple myeloma. Int J Hematol. 1994 Dec; 60(4):263-5. PMid:7894029

17. Yan H, Parsons DW, Jin G, et al. IDH1 and IDH2 mutations in gliomas. N Engl J Med. 2009;360(8):765-73. http://dx.doi.org/10.1056/NEJMoa0808710 PMid:19228619 PMCid:2820383

18. Dang L, White DW, Gross S, Bennett BD, Bittinger MA, Driggers EM, Fantin VR, Jang HG, Jin S, Keenan MC, Marks KM, Prins RM, Ward PS, Yen KE, Liau LM, Rabinowitz JD, Cantley LC, Thompson CB, Vander Heiden MG, Su SM. Cancer-associated IDH1 mutations produce 2-hydroxyglutarate. Nature. 2009 Dec 10;462(7274):739-44.

http://dx.doi.org/10.1038/nature08617

PMid:19935646 PMCid:2818760

19. Boissel N, Nibourel O, Renneville A, Gardin C, Reman O, Contentin N, Bordessoule D, Pautas C, de Revel T, Quesnel B, Huchette P, Philippe N, Geffroy S, Terre C, Thomas X, Castaigne S, Dombret H, Preudhomme C. Prognostic impact of isocitrate dehydrogenase enzyme isoforms 1 and 2 mutations in acute myeloid leukemia: a study by the Acute Leukemia French Association group.J Clin Oncol. 2010 Aug 10;28(23):3717-23. http://dx.doi.org/10.1200/JCO.2010.28.2285 PMid:20625116

20. Paschka P, Schlenk RF, Gaidzik VI, Habdank M, Krönke J, Bullinger L, Späth D, Kayser S, Zucknick M, Götze K, Horst HA, Germing U, Döhner H, Döhner K. IDH1 and IDH2 mutations are frequent genetic alterations in acute myeloid leukemia and confer adverse prognosis in cytogenetically normal acute myeloid leukemia with NPM1 mutation without FLT3 
internal tandem duplication. J Clin Oncol. 2010 Aug 1;28(22):3636-43. http://dx.doi.org/10.1200/JCO.2010.28.3762 PMid:20567020

21. Taghi Manshouri, Jay Patel, Kelly Harris, JinJuan Yao, Cyrus Hedvat, Adriana Heguy, Carlos Bueso-Ramos, Hagop
Kantarjian, Ross L. Levine, Omar Abdel-Wahab. Genetic analysis of leukemic transformation of chronic myeloproliferative neoplasms. Cancer Res. 2010 January 15; 70(2): 447-452. PMid:20068184 PMCid:2947340 